opinion that most of these cases are due to organisms of the pleuropneumonia group will be substantiated in the future remains to be seen; but it would seem that the present evidence hardly justifies so strong an expression of opinion. Nevertheless these views and this work in a neglected field are stimulating, and may well lead to further and fruitful investigations. There is an excellent and well illustrated account of the condition commonly known as Reiter's syndrome, but it is perhaps unfortunate that it should be called 'Reiter's Disease,' so adding to the existing confusion of nomenclature. The term for this condition which the author proposes, 'the non-gonococcal syndrome,' is so indefinite and so wide in its application that it can have little meaning. Infections with bilharzia are described briefly and well, but the suggestion that the urine should be examined for the ova in all cases of non-gonococcal urethritis seems to go too far, especially for routine work in this country.

The author is a man of strong views and some of them are unorthodox. They will not be generally accepted, and the reader who lacks special experience may well have difficulty in distinguishing between fact and opinion. Nevertheless the book should hold interest for everyone and will be of special value to the urologist and venereologist.

\section{THE CLOSED TREATMENT OF COMMON FRACTURES}

By John Charnley, B.Sc., M.B., F.R.C.S. Pp. $\mathrm{xi}+190$, with 133 illustrations. Edinburgh: E. \& S. Livingstone Ltd. 1950. 35 s.

This book provides stimulating thought and excellent guidance for the postgraduate dealing with casualty work. The real substance is not new but is simply and graphically portrayed and there are many practical and useful hints which should be of immense value to any house officer faced with fracture work for the first time.

Mr. Charnley expounds his principle of threepoint fixation fully, and the reader cannot help appreciating the value of the 'soft tissue hinge' in the manipulative reduction of the displacement in many common fractures. The danger of overdistraction is well stressed, and the author draws attention to certain fractures, including the supracondylar fracture of the humerus in childhood, which do not need plaster immobilization.

The views of the Italian school with regard to plaster technique are followed closely, contrasting directly with the Böhler technique which had such vogue in this country before the last war. The padded plaster is given its rightful place in conjunction with correct moulding at the fracture site.

In this country most orthopaedic surgeons would agree that many pertrochanteric fractures of the femur can be treated successfully by means of the Hamilton-Russell type of traction, and certainly the correct use of the Thomas splint and fixed traction in fractures of the lower third of the femur proved itself again in the last war at several orthopaedic centres.

The chapter on the walking caliper is full of in- formation both historical and practical and should correct many false ideas.

The book is very well illustrated and without $\stackrel{.}{.}$ question forms a useful supplement to the large and more classical textbooks on fractures, particularly $\stackrel{5}{+}$ at a time when so many fractures are being treated, 0 in certain parts of the world, by open methods only.

W.A.L.

\section{A SURGEON'S GUIDE TO LOCAL ANAESTHESIA}

By C. E. Corlette, M.D., Ch.M., F.R.A.C.S. $\vec{\circ}$ Pp. xi +355 , with 200 illustrations. Bristol: $\overrightarrow{\vec{H}}$ John Wright \& Sons. London: Simpkin Marshall. 1948. 35s.

This instructive book will serve as a good short $\frac{0}{3}$ cut to the surgeon who wishes to be able to find i the essentials of local anaesthesia recorded in brief o compass. It is the record of a very experienced $\omega$ general surgeon's personal knowledge of the subject, and is to be valued as the work of a man who has 9 taught throughout his career. His arguments are $\vec{f}$ well thought out and forcibly stated, and the de-은 tailed instructions are clear.

For such a short book, however, there is a con- $Z$ siderable amount of redundant material, such as? selected case reports. Some of the anatomical $\frac{\Phi}{3}$ diagrams are superfluous and some are not entire correct. In the opinion of most surgeons it is labouring a point to discuss the pros and cons $\vec{f}$ shockless surgery.

A.H.H.

\section{' CONCERNING ANAESTHESIA'}

A series of Papers reprinted from the Postgraduate Medical Journal 50 pages
50 2/- per copy

SPINAL ANALGESIA

By William W. Mushin, M.A., M.B., B.A., F.F.A., R.C.S. INHALATION ANAESTHESIA

By John Gillies, C.V.O., M.C., M.B., Ch.B., F.R.C.S.E., D.A. A SYSTEM OF ANAESTHESIA USING D-TUBocuRARINE CHLORIDE FOR CHEST SURGERY

By T. Cecil Gray, M.D., D.A., F.F.A., R.C.S.

ANALGESIA IN OESTETRICS

By P. J. Helliwell, M.B., Ch.B., D.A., and A. Michael Hutton, M.R.C.S., L.R.C.P., D.A.

GENERAL ANAESTHESIA FOR DENTAL SURGERY By W. S. McConnell, M.B., B.S., D.A.

REGIONAL ANAESTHESIA

By Alan Hunt, D.M., M.Ch., F.R.C.S. POST-OPERATIVE CARE

By John Beard, M.D., D.A.

Published by
THE
FELLOWSHIP OF POSTGRADUATE MEDICINE
I Wimpole Street, W.I

